\title{
HASIL BELAJAR BAHASA INGGRIS SISWA SMA PROGRAM BLOCK GRANT KECAKAPAN HIDUP
}

Oleh: Nurdin Ibrahim *

\section{Abstrak}

Penelitian ini bertujuan untuk mengetahui apakah terdapat perbedaan hasil belajar bahasa Inggris antara siswa yang memperoleh Block Grant dan yang tidak memperoleh Block Grant. Penelitian ini dilaksanakan pada SMA Negeri Jakarta yang mendapat Block Grant Kecakapan Hidup dan SMA Negeri Jakarta yang tidak mendapat Block Grant Kecakapan Hidup tahun 2003, yang terdapat di wilayah Jakarta Timur, Pusat dan Utara. Teknik analisis yang digunakan adalah Analysis of Variance (ANOVA) dengan uji lanjut Tukey pada $\alpha=0,05$. Penelitian ini jenis expo facto dan rancangan penelitian yang digunakan adalah penelitian faktorial $2 \times 2$.

Hasil yang diperoleh menunjukkan bahwa: Pertama, secara keseluruhan terdapat perbedaan yang signifikan antara hasil belajar bahasa Inggris siswa yang memperoleh Block Grant dengan yang tidak memperoleh Block Grant. Kedua, terdapat interaksi antara pemberian dana bantuan Block Grant dan kemampuan awal terhadap hasil belajar bahasa Inggris siswa.

Kata kunci: Block grant, kecakapan hidup, belajar, hasil belajar, bahasa Inggris

\section{PENDAHULUAN}

\section{A. Latar Belakang}

Memasuki abad ke-21, sistem pendidikan nasional menghadapi tantangan yang sangat kompleks dalam menyiapkan kualitas sumberdaya manusia (SDM) yang mampu bersaing di era global.

*) Dr. Nurdin Ibrahim; Dosen Universitas Negeri Jakarta. 
Krisis multi dimensi yang terjadi sejak tahun 1997 berpengaruh terhadap kinerja program-program pembangunan pendidikan nasional (Depdiknas, 2001:11). Pengaruh langsung krisis terhadap pendidikan adalah menurunnya kemampuan orangtua siswa untuk membiayai pendidikan anak-anaknya, terutama pada masyarakat lapisan bawah. Anak-anak mereka sulit mengenyam pendidikan bermutu karena impitan ekonomi dan biaya pendidikan yang terlampau mahal. Gejala ini mengakibatkan meningkatnya jumlah angka putus sekolah dan meningkatnya anak-anak usia sekolah yang terpaksa bekerja pada berbagai lapangan kerja.

Struktur tenaga kerja di Indonesia lebih banyak didominasi orangorang berpendidikan rendah. Data tahun 2000 menunjukkan, komposisi angkatan kerja yang mengenyam pendidikan tingkat sekolah dasar ke bawah mencapai 59 persen. Sementara angkatan kerja lulusan sekolah lanjutan tingkat pertama dan SLTA masing-masing 16,06 persen dan 19,44 persen. Sementara itu angkatan kerja berpendidikan tinggi berjumlah sangat sedikit, yakni 4,6 persen (Alhumani: 2004:42).

Sementara itu Pendidikan Nasional dihadapkan kepada berbagai masalah antara lain peningkatan kualitas dan relevansi pendidikan yaitu masih rendahnya prosentase lulusan SMU yang memenuhi persyaratan untuk masuk ke perguruan tinggi, dan terbatasnya anggaran yang tersedia dan belum terpenuhi sumber daya dari masyarakat secara profesional. Peningkatan mutu dan relevansi pendidikan dikaitkan dengan tuntutan kemajuan Iptek dan persaingan yang tajam antara negara dalam penguasaan, pengembangan, dan pemanfaatan Iptek untuk pembangunan (Nanang Fattah: 2002:78-80). Adapun salah satu tantangan yang dihadapi oleh pemerintah dalam penyelenggaraan pendidikan menegah umum adalah menyiapkan siswa memasuki perguruan tinggi, baik akademik maupun profesional di dalam maupun di luar negeri, penguasaan bahasa asing khususnya bahasa Inggris sebagai bahasa sains dan teknologi (Depdiknas: 2001:61). 
Di sisi lain berdasarkan data tahun 2002/2003 (Depdiknas: 2003: 156) lulusan SMA di Indonesia sebanyak 935.127 orang. Dari jumlah itu yang tidak melanjutkan ke Perguruan Tinggi (negeri dan swasta) hampir $90 \%$. Hal ini berarti mereka yang tidak melanjutkan ke Perguruan Tinggi akan masuk ke dunia kerja, terutama sekali bagi mereka yang berasal dari keluarga yang berstatus sosial ekonomi di bawah rata-rata atau tidak mampu.

Berdasarkan Program Pembangunan Nasional lima tahun (Propenas) Depsdiknas (2001: 66-69) tahun 2000-2004 menetapkan kegiatan-kegiatan pokok sasaran pembangunan pendidikan menengah di antaranya adalah (1) meningkatkan standar mutu nasional secara bertahap agar lulusan pendidikan menengah mampu bersaing dengan lulusan pendidikan menengah di negara-negara lain, (2) mengembangkan program-program keterampilan/kejuruan pada SMU dan MA yang sesuai dengan lingkungan setempat atau tuntutan dunia kerja setempat agar para lulusan SMU dan MA yang tidak memiliki peluang untuk melanjutkan ke perguruan tinggi dapat bersaing dalam memasuki dunia kerja. dan (3) mengembangkan pendekatan pembelajaran yang inovatif atau yang mampu memacu proses belajar yang maksimal serta mencapai prestasi yang tinggi

Atas dasar itu maka sejak tahun 2001/2002 Pemerintah dalam hal ini Depdiknas menetapkan suatu kebijakan untuk meningkatkan pendidikan kecakapan hidup (life skills) dengan pemberian "block-grant" berupa bantuan uang kepada SMA secara bertahap. Jumlah SMA yang telah mendapat "blockgrant' sampai tahun 2004 sejumlah 1911 sekolah. Khusus untuk propinsi DKI Jakarta jumlah SMA Negeri dan swasta yang telah mendapat "block-grant"sampai tahun 2004 berjumlah 72 sekolah dengan rincian 20 sekolah pada tahun 2002, 39 sekolah pada tahun 2003 dan 13 sekolah pada tahun 2004.

Adapun program-program yang dilaksanakan oleh penerima block-grant (Depdiknas, 2004:12) mencakup sebagai berikut (1) 
reorientasi pembelajaran; (2) pembekalan kecakapan vokasional; dan (3) pengembangan Manajemen Peningkatan Mutu Berbasis Sekolah. Reorientasi pembelajaran dimaksudkan sebagai upaya meningkatkan kemampuan akademik siswa terutama mata pelajaran bahasa Inggris sebagai dasar untuk mempersiapkan mereka melanjutkan ke perguruan tinggi.

Bahasa Inggris (Depdikbud. 1993: 1) merupakan bahasa internasional yang banyak digunakan oleh setiap orang di seluruh penjuru dunia terutama di era globalisasi ini. Bahasa menjadi alat komunikasi efektif yang memungkinkan setiap orang yang berbeda bangsa dapat saling berinteraksi. Kemampuan berinteraksi sosial dengan semua pihak (Communication Skil) dengan menggunakan bahasa Inggris menjadi tuntutan profesionalisme dalam dunia kerja. Oleh karena itu peningkatan mutu bahasa Inggris di kalangan siswa khususnya siswa SMA harus diprioritaskan.

Untuk mengetahui sejauh mana pengaruhnya pemberian blockgrant terhadap hasil belajar bahasa Inggris siswa SMA di DKI Jakarta, maka dilakukan suatu penelitian tentang: "Pengaruh Block Grant Kecakapan Hidup Terhadap Hasil Belajar Bahasa Inggris di SMA Negeri Jakarta"

\section{B. Masalah, tujuan, dan hipotesis penelitian}

Permasalahannya adalah "(a) apakah terdapat perbedaan hasil belajar bahasa Inggris antara siswa SMA Negeri di DKI Jakarta yang mendapat block grant dengan yang tidak mendapat block grant, dan (b) Apakah terdapat interaksi (pemberian block grant dan non-block grant) dan kemampuan awal (tinggi dan rendah) terhadap hasil belajar bahasa Inggris".

Tujuan dari penelitian ini adalah untuk memperoleh informasi mengenai. (a) Perbedaan hasil belajar Bahasa Inggris antara siswa SMA Negeri di DKI Jakarta yang memperoleh block-grant dengan yang tidak memperoleh block-grant, dan (b) Interaksi 
antara pemberian (block grant dan non-block grant) dan kemampuan awal (tinggi dan rendah) terhadap hasil belajar bahasa Inggris siswa".

Penelitian ini menggunakan hipotesis deskriptif sebagai berikut. (a) "Terdapat perbedaan hasil belajar Bahasa Inggris antara siswa SMA Negeri di DKI Jakarta yang memperoleh block-grant dengan yang tidak memperoleh block-grant, dan (b) Terdapat interaksi antara pemberian block grant dengan kemampuan awal terhadap hasil belajar bahasa Inggris siswa".

\section{KAJIAN PUSTAKA}

\section{A. Hakikat Block Grant Kecakapan Hidup}

Block Grant adalah bantuan berupa uang yang diberikan oleh pemerintah dalam hal ini Departemen Pendidikan Nasional kepada sekolah-sekolah khususnya SMP dan SMA untuk melaksanakan pendidikan keterampilan atau kecakapan hidup (life skills) bagi siswanya. Menurut CEFS yang dikutip Illinois Department of Commerce and Economic Opportunity (DCEO) berpendapat bahwa program Block Grant menyediakan bidang jasa yang membantu orang-orang yang kurang mampu mencapai keterampilan, motivasi dan pengetahuan yang diperlukan agar dapat mandiri (http://www.advant.com/cefs/csbg.htm: 1.)

Di Indonesia (Depdiknas, 2004) pemberian subsidi ke sekolah dalam bentuk block grant secara umum di antaranya bertujuan untuk:

1. Meningkatkan mutu dan relevansi pendidikan melalui penyelenggaraan pembelajaran yang bermutu.

2. Mendorong sekolah untuk melaksanakan Manajemen Berbasis Sekolah (MBS) dalam rangka meningkatkan efektivitas dan efisiensi penyelenggaraan pendidikan di sekolah. 
Berkaitan dengan pelaksanaan block grant di SMP dan SMA program-program yang dipilih hendaknya diutamakan yang berkaitan dengan penguasaan sains, matematika, dan bahasa khususnya bahasa Inggris. Kecakapan Hidup (Life skills) fokus pada pengajaran keterampilan kesiapan bersama dengan keterampilan hidup sehari-hari. Para siswa belajar keterampilan hidup yang mereka dapat sehingga mereka dapat menerapkannya dalam kehidupan sehari-hari. Adapun visi dari program life skills (http://www.wpsweb.com/GatesLane/ life\%20skills.htm. 2005:1) adalah agar para siswa menjadi semandiri mungkin sehingga mereka dapat secepatnya belajar cara yang secara individual berbeda terhadap masing-masing orang agar menjadi anggota penyokong dalam masyarakat. Selanjutnya disebutkan bahwa Life skills (kecakapan hidup) meningkat sebagai hasil langsung dari program tandingan yang terdiri dari academic achievement, self-esteem, connectiveness to school and community, communication, decision-making/ problem-solving, and conflict resolution/violence prevention.

Landasan yuridis pendidikan kecakapan hidup (life skills) dapat mengacu pada UU Nomor 20 Tahun 2003 tentang Sistem Pendidikan Nasional. Pada Pasal 1 ayat (1) dijelaskan bahwa pendidikan adalah usaha sadar dan terencana untuk mewujudkan suasana belajar dan proses pembelajaran agar peserta didik secara aktif mengembangkan potensi dirinya untuk memiliki kekuatan spiritual keagamaan, pengendalian diri, kepribadian, kecerdasan, akhlak mulia, serta keterampilan yang diperlukan dirinya, masyarakat, bangsa dan negara. Pendidikan pada dasarnya merupakan Pendidikan Kecakapan Hidup. Jadi pada akhirnya tujuan pendidikan adalah membantu peserta didik agar nantinya mampu meningkatkan dan mengembangkan dirinya sebagai pribadi yang mandiri, sebagai anggota masyarakat dan sebagai warga negara.

Secara umum pendidikan kecakapan hidup (life skills) bertujuan memfungsikan pendidikan sesuai dengan fitrahnya, yaitu 
mengembangkan potensi manusiawi peserta didik untuk menghadapi perannya di masa datang. Sedangkan manfaat pendidikan berorientasi pada kecakapan hidup bagi peserta didik adalah sebagai bekal dalam menghadapi dan memecahkan problema hidup dan kehidupan, baik sebagai pribadi yang mandiri, warga masyarakat, maupun sebagai warga negara. Jika hal itu dapat dicapai, maka faktor ketergantungan terhadap lapangan pekerjaan yang sudah ada dapat diturunkan, yang berarti produktivitas nasional akan meningkat secara bertahap Peningkatan produktivitas nasional akan mempengaruhi pembangunan ekonomi. Sehingga secara tidak langsung kecakapan hidup memberi kontribusi terhadap pembangunan ekonomi.

\section{B. Hakikat Hasil Belajar Bahasa Inggris}

Poerwadarminta (2002:75) mengatakan bahwa bahasa adalah sistem lambang bunyi (tanda yang berupa sembarang bunyi (bunyi=bahasa)) yang dipakai orang untuk melahirkan pikiran dan perasaan; misalnya memperluas pengetahuan. Lambang bunyi yang dihasilkan ini berbeda pada setiap daerah, oleh karena itu untuk memahami suatu bahasa yang dipakai oleh daerah tertentu, seorang manusia harus mempelajari lambang bunyi/ bahasa yang digunakan oleh daerah tersebut.

Dalam Kurikulum berbasis kompetensi SMA bidang studi bahasa Inggris dan bahasa asing (Depdiknas, http://www.puskur.or.id) memiliki kompetensi yang diharapkan yaitu: 1) Menyimak: menafsirkan isi berbagai bentuk teks lisan dan meresponnya dalam bentuk kegiatan yang beragam; 2) Berbicara: berbicara secara efektif dalam berbagai konteks untuk menyampaikan informasi, pikiran dan perasaan serta menjalin hubungan sosial; 3) Membaca: menafsirkan isi berbagai bentuk teks tulis dan merespon dalam bentuk kegiatan yang beragam; 4) Menulis: menulis kreatif berbagai bentuk teks untuk menyampaikan informasi dan mengungkapkan pikiran serta perasaan; 5) 
Apresiasi sastra: menghayati dan menghargai karya sastra; 6) Sikap: menghargai budaya positif dan bahasa yang dipelajari.

Kompetensi di atas merupakan uraian kemampuan yang harus dimiliki siswa untuk menguasai suatu bahasa asing. Siswa menggunakan bahasa untuk memahami, mengembangkan, mengkomunikasikan gagasan dan informasi, serta untuk berinteraksi dengan orang lain. Siswa dapat mempelajari kemampuan tersebut secara bertahap dan akan lebih efektif jika siswa sering mempraktekkannya dalam kehidupan sehari-hari.

Proses pembelajaran bahasa Inggris perlu dilaksanakan dengan melibatkan peran aktif siswa dan memanfaatkan media yang mendukung proses pembelajaran. Hal ini sesuai dengan pendapat Kariman (2002:6) proses pembelajaran konvensional secara bertahap harus memanfaatkan media dan multimedia, agar lebih berkualitas. Perkembangan ilmu pengetahuan dan teknologi yang semakin maju pesat menuntut tersedianya media dan multimedia yang menunjang pembelajaran di kelas maupun dalam pembelajaran mandiri.

Sementara itu belajar merupakan suatu terminologi yang menggambarkan suatu proses perubahan melalui pengalaman. Proses tersebut mempersyaratkan perubahan yang relatif permanen berupa sikap, pengetahuan, informasi, kemampuan, dan keterampilan melalui pengalaman. Menurut Gagne (1977:4950), belajar adalah suatu perubahan dalam disposisi atau kapabilitas manusia. Perubahan dalam menunjukkan kinerja (perilaku) itu sendiri disebut belajar. Peningkatan (hasil) belajar dapat dilakukan dengan membandingkan penampilan kapabilitas (kinerja) sebelum masuk ke dalam kondisi belajar dengan penampilan sesudah melakukan belajar. Ini berarti bahwa (hasil) belajar itu merupakan semua keterampilan, pengetahuan, sikap dan nilai yang diperoleh individu (siswa). 
Gagne dan Briggs membagi hasil belajar menjadi lima kategori kapabilitas yaitu (1) keterampilan intelektual (intellectual skills), (2) strategi kognitif (cognitive strategies), (3) informasi verbal (verbal information), (4) keterampilan motorik (motor skills), dan (5) sikap (attitudes). Keterampilan intelektual adalah kecakapan yang berkenaan dengan pengetahuan prosedural, mulai dari kemampuan membedakan, konsep konkret, konsep definisi, kaidah serta kaidah yang lebih tinggi; kaidah yang mengandung banyak langkah disebut prosedur (Gagne, 1989:90).

Bloom dan kawan-kawannya, sebagaimana dikutip oleh Degeng (1989:176-177), mengklasifikasikan hasil pengajaran (belajar) menjadi tiga domain atau ranah, yaitu ranah kognitif, psikomotor, dan sikap. Ranah kognitif menaruh perhatian pada pengembangan kapabilitas dan keterampilan intelektual; ranah psikomotor berkaitan dengan kegiatan-kegiatan manipulatif atau keterampilan motorik; dan ranah sikap berkaitan dengan pengembangan perasaan, sikap, nilai, dan emosi.

Reigeluth (1983:20) mengatakan bahwa hasil pembelajaran secara umum dapat dikategorisasi menjadi tiga kelas atau level, yaitu (1) keefektifitas pembelajaran, yang biasanya diukur dari tingkat keberhasilan (prestasi) siswa dari berbagai sudut, (2) efisiensi pembelajaran, yang biasanya diukur dari waktu belajar dan/atau biaya pembelajaran, dan (3) daya tarik pembelajaran yang selalu diukur dari tendensi siswa ingin belajar secara kontinu. Secara spesifik, hasil belajar adalah suatu kinerja (performance) yang diindikasikan sebagai suatu kapabilitas (kemampuan) yang telah diperoleh.

Dari uraian di atas dapat disimpulkan bahwa hasil belajar Bahasa Inggris siswa SMA adalah seberapa banyak siswa menguasai atau mencapai tujuan-tujuan pembelajaran (umum dan khusus) yang telah ditetapkan dalam kurikulum yang berlaku. Dengan kata lain, seberapa banyak materi-materi pembelajaran yang telah 
ditetapkan dalam kurikulum telah dikuasai oleh siswa. Adapun hasil belajar Bahasa Inggris siswa SMA yang dimaksud dalam penelitian ini adalah nilai Bahasa Inggris semester V.

\section{METODOLOGI PENELITIAN}

Penelitian ini dilaksanakan di DKI Jakarta, berlangsung selama bulan April-Mei 2005.

\section{A. Metode Penelitian}

Penelitian ini menggunakan metode ex post facto. Yang dimaksud dengan penelitian ex post facto (Furchan, 1982:384) adalah dimulai dengan menggambarkan keadaan sekarang, yang dianggap sebagai akibat dari faktor-faktor yang terjadi sebelumnya, kemudian mencoba menyelidiki ke belakang guna menetapkan faktor-faktor yang diduga sebagai penyebab, yang sudah beroperasi di masa lalu. Penelitian ini untuk mengetahui pengaruh reorientasi pembelajaran melalui block grant kecakapan hidup yang diberikan pada tahun 2003 (perlakuan pada semester III dan IV) terhadap hasil belajar bahasa Inggris siswa SMA semester V. Sebagai variabel kontrol adalah nilai UAN SMP siswa ketika masuk ke SMA.

Rancangan penelitian dapat ditunjukkan dalam tabel 3.1. berikut

Tabel 3.1 Rancangan Faktorial $2 \times 2$

\begin{tabular}{|c|c|c|}
\hline \multirow{2}{*}{$\begin{array}{c}\text { Kemampuan } \\
\text { Awal }(B)\end{array}$} & \multicolumn{2}{|c|}{ Status Bantuan Dana (A) } \\
\cline { 2 - 3 } & $\begin{array}{c}\text { Block Grant } \\
\left(A_{1}\right)\end{array}$ & $\begin{array}{c}\text { Tanpa Block Grant } \\
\left(A_{2}\right)\end{array}$ \\
\hline Tinggi $\left(B_{1}\right)$ & $A_{1} B_{1}$ & $A_{2} B_{1}$ \\
\hline Rendah $\left(B_{2}\right)$ & $A_{1} B_{2}$ & $A_{2} B_{2}$ \\
\hline
\end{tabular}


Keterangan :

$\mathrm{A}_{1} \mathrm{~B}_{1}=$ Siswa SMA Negeri dengan kemampuan awal tinggi yang memperoleh block-grant.

$\mathrm{A}_{2} \mathrm{~B}_{1}=$ Siswa SMA Negeri dengan kemampuan awal tinggi yang tidak memperoleh block-grant.

$A_{1} B_{2}=$ Siswa SMA Negeri dengan kemampuan awal rendah yang memperoleh block-grant.

$\mathrm{A}_{2} \mathrm{~B}_{2}=$ Siswa SMA Negeri dengan kemampuan awal rendah yang tidak memperoleh block-grant.

\section{B. Teknik Pengumpulan Data}

Alat pengumpulan data yang digunakan adalah kuesioner dan pedoman observasi. Kuesioner digunakan untuk mengumpulkan data mengenai hasil pelaksanaan program kebijakan block-grant, jenis kelamin, jurusan siswa, lama waktu mengikuti kursus/ bimbel, media pembelajaran, dan tingkat pendidikan guru. Sementara pedoman observasi digunakan untuk memperoleh data yang berkaitan hasil (produk) seperti nilai UAN Bahasa Inggris dan nilai Bahasa Inggris semester V. Adapun data yang digunakan dalam penelitian ini adalah data cross-section. Data siswa SMA yang digunakan adalah siswa kelas III (pada saat penelitian) pada 8 SMA Negeri di DKI Jakarta pada tahun 2003/ 2004, yang diasumsikan memperoleh program reorientasi pembelajaran bahasa Inggris pada semester III, IV dan V.

Uji validitas instrumen penelitian ini menggunakan uji validitas logis melalui validitas muka/isi.

\section{Populasi dan Sampel}

Populasi target dalam penelitian ini seluruh siswa SMA Negeri di wilayah DKI Jakarta, sedangkan populasi terjangkau adalah siswa SMAN yang ada di wilayah Kodya Jakarta Timur, Utara dan Pusat. Adapun sampelnya adalah siswa kelas III pada sekolah yang memperoleh block-grant kecakapan hidup tahun 2003 dan siswa kelas III SMAN yang tidak memperoleh block- 
grant kecakapan hidup pada wilayah yang sama dan setara dengan sekolah yang dapat block grant.

Penentuan lokasi sampel dilakukan secara random purposive sample yaitu dengan kriteria sekolah-sekolah yang memilih program pendidikan kecakapan hidup (life skills) yang sama atau sejenis yaitu program reorientasi pembelajaran Bahasa Inggris.

Lokasi penelitian dapat dilihat pada tabel 3.3 di bawah ini.

Tabel 3.2. Lokasi Sebagai Sumber Data Penelitian

\begin{tabular}{|l|l|l|l|}
\hline No. & Wilayah & SMA Block Grant & SMA Non Block Grant \\
\hline 1. & Jakarta Timur & SMAN 31, Kayu Manis & SMAN 36, Rawamangun \\
\hline 2. & Jakarta Timur & SMAN 76, Cakung & SMAN 11, Cakung \\
\hline 3. & Jakarta Pusat & SMAN 20, Kota & SMAN 10, Kota \\
\hline 4. & Jakarta Utara & SMAN 15, Sunter & SMAN 40, Sunter \\
\hline
\end{tabular}

\section{Teknik Analisis Data}

Teknik analisis data dilakukan dengan dua cara, yaitu dengan analysis of variance (ANOVA) yang dilanjutkan dengan uji Tukey.

Analysis of Variance (ANOVA) adalah teknik analisis yang digunakan dalam penelitian ini adalah Analysis of Variance (ANOVA) - dua jalur pada taraf sangat signifkansi $=0,01$ dan $/$ atau taraf signifikansi $=0,05$ (Ary, Jacob, dan Razawiech, 1985:279). Analysis of variance adalah suatu teknik statistik yang digunakan untuk menguji suatu hipotesis yang menyatakan tidak ada perbedaan antara perlakuan $\left(\mathrm{H}_{0}\right)$ dengan suatu hipotesis alternatif yang menyatakan ada perbedaan $\left(\mathrm{H}_{1}\right)$ Gravetter dan Wallnau (1985:43).

Sebelum data hasil penelitian dianalisis secara statistik, terlebih dahulu dilakukan uji persyaratan yang meliputi uji normalitas dan 
uji homogenitas populasi. Uji normalitas yang dilakukan menggunakan uji Lilliefors, sedangkan uji homogenitas menggunakan uji Barrlett (Sudjana, 1992:466-467). Adapun hipotesa statistik dalam uji ANOVA adalah.
a. $H_{0}: \mu A_{1}=\mu A_{2}$
$H_{1}: \mu A_{1}>\mu A_{2}$
b. $H_{0}: A \times B=0$
$H_{1}: A \times B \quad 0$

\section{HASIL PENELITIAN}

\section{A. Deskripsi Data}

Berikut ini disajikan secara deskripsi data hasil belajar bahasa Inggris siswa. Besaran yang akan disajikan adalah jumlah sampel, skor rata-rata (mean) dan simpangan baku (standar deviasi).

Perbandingan kemampuan awal bahasa Inggris siswa yang memperoleh block grant dan yang tidak memperoleh block grant dapat dilihat pada tabel 4.1 berikut ini.

Tabel 4.1. Rangkuman Data

\begin{tabular}{|c|c|c|c|}
\hline \multirow{2}{*}{$\begin{array}{c}\text { Kemampuan } \\
\text { Awal } \\
\text { (B) }\end{array}$} & \multicolumn{2}{|c|}{ Status Bantuan Dana (A) } & \multirow{2}{*}{ 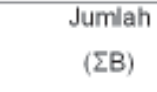 } \\
\hline & $\begin{array}{c}\text { Block Grant } \\
\left(\mathrm{A}_{1}\right)\end{array}$ & $\begin{array}{c}\text { Non Block Grant } \\
\left(\mathrm{A}_{2}\right)\end{array}$ & \\
\hline $\begin{array}{c}\text { Tinggi } \\
\left(\mathrm{B}_{1}\right)\end{array}$ & $\begin{array}{l}n=66 \\
\bar{X}=6,34 \\
\text { Sd }=1,00\end{array}$ & $\begin{array}{l}\mathrm{n}=66 \\
\bar{X}=6,10 \\
\mathrm{Sd}=1,16\end{array}$ & $\begin{array}{l}\mathbf{n}=132 \\
\bar{X}=6,22 \\
\text { Sd }=1,09\end{array}$ \\
\hline $\begin{array}{l}\text { Rendah } \\
\left(\mathrm{B}_{2}\right)\end{array}$ & $\begin{array}{l}n \quad=66 \\
\bar{X}=5,29 \\
\text { Sd }=1,13\end{array}$ & $\begin{aligned} n & =66 \\
\bar{X} & =4,38 \\
\text { Sd } & =1,04\end{aligned}$ & $\begin{array}{l}n=132 \\
\bar{X}=4,83 \\
\text { Sd }=1,18\end{array}$ \\
\hline 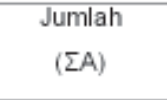 & $\begin{array}{l}n=132 \\
\bar{X}=5,82 \\
\text { Sd }=1,19\end{array}$ & $\begin{array}{l}n=132 \\
\bar{X}=5,24 \\
\text { Sd }=1,40\end{array}$ & $\begin{array}{l}n=264 \\
\bar{X}=5,53 \\
S d=1,33\end{array}$ \\
\hline
\end{tabular}


Keterangan:

$\mathrm{n}$ = jumlah sampel

= skor rata-rata (mean)

$\mathrm{Sd}=$ standar deviasi

\section{B. Pengujian Hipotesis}

Teknik yang digunakan untuk menguji hipotesis penelitian adalah analisis varians dua jalur dilanjutkan dengan Tukey'S HDS test.

Dari data hasil belajar bahasa Inggris, setelah dilakukan perhitungan diperoleh hasil varians seperti dalam tabel 4.2. berikut.

Tabel 4.2. Hasil Perhitungan ANOVA Dua Jalur

\begin{tabular}{|c|c|c|c|c|c|c|}
\hline Sumber Variansi & JK & dk & RJK & $F_{\text {rut }}$ & \multicolumn{2}{|c|}{$F_{\text {tab }}$} \\
\cline { 6 - 8 } & & & & & 0,05 & 0,01 \\
\hline Antar Kolom (A) & 22,099 & 1 & 22,099 & $18,77^{* \star}$ & 3,88 & 6,75 \\
Antar Baris (B) & 126,60 & 1 & 126,60 & $107,56^{* *}$ & 3,88 & 6,75 \\
Interaksi (AxB) & 7,361 & 1 & 7,361 & $6,25^{*}$ & 3,88 & 6,75 \\
Dalam Kelompok & 306,03 & 260 & 1,177 & - & - & - \\
\hline Total Direduksi & 462,09 & 263 & - & - & - & - \\
\hline
\end{tabular}

Keterangan:

$\star * \quad=$ Sangat Signifikan

* $\quad=$ Signifikan

JK = Jumlah Kuadrat

RJK = Rerata Jumlah Kuadrat

Fhit $\quad=F$ hitung

$\mathrm{Ftab}=\mathrm{F}$ tabel

1. Perbedaan Hasil Belajar Bahasa Inggris Siswa pada sekolah Memperoleh Block Grant dan tidak Memperoleh Block Grant Dari data diperoleh skor rata-rata hasil belajar Bahasa Inggris kelompok siswa pada sekolah yang memperoleh block grant 
sebesar 5,82 dan simpangan baku 1,19, sedangkan untuk kelompok siswa pada sekolah yang tidak memperoleh block grant hasil belajar Bahasa Inggrisnya sebesar 5,24 dan simpangan baku 140.

Berdasarkan hasil perhitungan analisis varians dua jalur (lihat tabel 4.1.) menunjukkan bahwa harga $F_{\text {hitung }}$ sebesar 18,77, sedangkan harga $\mathrm{F}_{\text {tabel }}$ sebesar 3,88 pada taraf signifikansi $=0,05$, dan $F_{\text {tabel }}$ sebesar 6,75 pada taraf signifikansi $=0,01$. Tampak $F_{\text {hitung }}>F_{\text {tabel}}$, maka hipotesis nol ditolak. Hal ini berarti bahwa terdapat perbedaan yang sangat signifikan antara hasil belajar Bahasa Inggris siswa pada sekolah yang memperoleh block grant dengan siswa pada sekolah yang tidak memperoleh block grant.

Di samping itu berdasarkan data $=5,82>=5,24$; berarti hasil belajar Bahasa Inggris siswa pada sekolah yang memperoleh block grant lebih tinggi dibandingkan siswa pada sekolah yang tidak memperoleh block grant. Dalam hal ini dapat dikatakan bahwa pemberian block grant terbukti memberikan pengaruh yang lebih efektif terhadap hasil belajar Bahasa Inggris siswa. Dapat disimpulkan bahwa secara umum hasil belajar siswa pada sekolah yang diberi block grant lebih baik daripada siswa pada sekolah yang tidak diberi block grant.

Untuk melihat apakah perbedaan tersebut signifikan atau tidak dilanjutkan dengan Uji Tukey. Dari hasil uji Tukey diperoleh hasil sebagai berikut. 
Tabel 4.3. Uji Tukey Hasil Belajar Bahasa Inggris antara Sekolah Memperoleh Block Grant dan tidak Memperoleh Block Grant.

\begin{tabular}{|c|l|l|l|}
\hline Kelompok yang dibandingkan & $\mathrm{q}_{\text {hitung }}$ & $\mathrm{q}_{\text {tabel }}$ & Kesimpulan \\
\hline $\mathrm{A}_{1}$ dan $\mathrm{A}_{2}$ & $6,44^{\star}$ & 2,77 & $\mathrm{~A}_{1}>\mathrm{A}_{2}$ \\
\hline
\end{tabular}

Keterangan:

* $\quad=$ Signifikansi pada $=0,05$

$A_{1}=$ Sekolah yang memperoleh block grant.

$A_{2}=$ Sekolah yang tidak memperoleh block grant.

Berdasarkan hasil uji lebih lanjut dengan menggunakan uji Tukey pada taraf signifikansi $=0,05$ (lihat tabel 4.2.) menunjukkan bahwa $\mathrm{q}_{\text {hitung }}=6,44$ lebih besar daripada $q_{\text {tabel }}=2,77$. Nilai rata-rata kelompok siswa pada sekolah yang memperoleh block grant $=5,82$ lebih besar dibandingkan dengan kelompok siswa pada sekolah yang tidak memperoleh block grant yang nilai rata-ratanya 5,24. Jadi hipotesis penelitian yang menyatakan bahwa secara keseluruhan terdapat perbedaan antara hasil belajar Bahasa Inggris kelompok siswa pada sekolah yang memperoleh block grant dengan kelompok siswa pada sekolah yang tidak memperoleh block grant teruji kebenarannya.

2. Interaksi antara Pemberian Dana Bantuan Block Grant dan Kemampuan Awal terhadap Hasil Belajar Bahasa Inggris Dari hasil penelitian diperoleh data (lihat tabel 4.1) sebagai berikut: (1) dengan kemampuan awal tinggi, rata-rata hasil belajar bahasa Inggris pada sekolah yang memperoleh block grant sebesar 6,34 lebih besar dibandingkan dengan sekolah yang tidak memperoleh block grant sebesar 6,10 dan (2) dengan kemampuan awal rendah, rata-rata hasil belajar bahasa Inggris pada sekolah yang memperoleh block grant 
sebesar 5,29 lebih besar daripada sekolah yang tidak memperoleh block grant 4,38.

Dari perhitungan dengan analisis varians dua jalur diperoleh $F_{\text {hitung }}$ sebesar 6,25, sedangkan $F_{\text {tabel }}$ sebesar 3,88 pada taraf signifikansi $=0,05$. Tampak bahwa $F_{\text {hitung }}>F_{\text {tabel }}$. Dengan demikian, hipotesis nol ditolak. Kesimpulan hipotesis penelitian yang menyatakan bahwa terdapat interaksi antara pemberian dana bantuan block grant dengan kemampuan awal terhadap hasil belajar Bahasa Inggris teruji kebenarannya.

Untuk melihat pengaruh hasil interaksi tersebut, dilanjutkan dengan Uji Tukey yang hasilnya dapat dilihat pada tabel 4.3.

Tabel 4.4. Hasil Rangkuman Uji Tukey pada Kelompok Perlakuan dan Kontrol

\begin{tabular}{|l|l|l|l|}
\hline $\begin{array}{l}\text { Kelompok Perlakuan } \\
\text { yang Dibandingkan }\end{array}$ & $\mathrm{q}_{\text {hitung }}$ & $\mathrm{q}_{\text {tabel }} \alpha=0,05$ & Kesimpulan \\
\hline $\mathrm{A}_{1}$ dengan $\mathrm{A}_{2}$ & $6,44^{\mathrm{s}}$ & 2,77 & $\mathrm{~A}_{1}>\mathrm{A}_{2}$ \\
\hline $\mathrm{A}_{1} \mathrm{~B}_{1}$ dengan $\mathrm{A}_{2} \mathrm{~B}_{1}$ & $1,85^{\mathrm{ts}}$ & 3,63 & $\mathrm{~A}_{1} \mathrm{~B}_{1}<\mathrm{A}_{2} \mathrm{~B}_{1}$ \\
\hline $\mathrm{A}_{1} \mathrm{~B}_{2}$ dengan $\mathrm{A}_{2} \mathrm{~B}_{2}$ & $7,00^{\mathrm{s}}$ & 3,63 & $\mathrm{~A}_{1} \mathrm{~B}_{2}>\mathrm{A}_{2} \mathrm{~B}_{2}$ \\
\hline
\end{tabular}

Keterangan:

$\mathrm{s} \quad=$ signifikan pada $=0,05$

ts $\quad=$ tidak signifikan pada $=0,05$

$A_{1} B_{1}=$ siswa dengan kemampuan awal tinggi mendapat block grant.

$\mathrm{A}_{2} \mathrm{~B}_{1}=$ siswa dengan kemampuan awal tinggi tidak mendapat block grant.

$\mathrm{A}_{1} \mathrm{~B}_{2}=$ siswa dengan kemampuan awal rendah memperoleh block grant.

$\mathrm{A}_{2} \mathrm{~B}_{2}=$ siswa dengan kemampuan awal rendah tidak memperoleh block grant. 
(1) $A_{1}$ dengan $A_{2}$

Hasil belajar bahasa Inggris sekolah yang memperoleh block grant $(=5,82)$ lebih tinggi dibandingkan dengan sekolah yang tidak memperoleh block grant $(=5,24)$, dengan harga $\mathrm{q}_{\text {hitung }}=$ 6,44 lebih besar dari $q_{\text {tabel }}=2,77$ pada taraf signifikansi $=$ 0,05 .

(2) $A_{1} B_{1}$ dengan $A_{2} B_{1}$

Hasil belajar bahasa Inggris siswa yang mempunyai kemampuan awal tinggi yang memperoleh block grant $(=6,34)$ tidak berbeda dibandingkan dengan siswa yang tidak mempunyai kemampuan awal tinggi yang tidak memperoleh block grant $(=6,10)$, dengan harga $q_{\text {hitung }}=1,85$ lebih kecil dari $q_{\text {tabel }}=3,63$ pada taraf signifikansi $=0,05$.

(3) $A_{1} B_{2}$ dengan $A_{2} B_{2}$

Hasil belajar bahasa Inggris siswa yang memperoleh block grant yang mempunyai kemampuan awal rendah $(=5,29)$ lebih tinggi dibandingkan dengan siswa yang tidak memperoleh block grant yang mempunyai kemampuan awal rendah $(=4,38)$, dengan harga $q_{\text {hitung }}=7,00$ lebih besar dari $q_{\text {tabel }}=3,63$ pada taraf signifikansi $=0,05$.

\section{KESIMPULAN, IMPLIKASI, DAN SARAN}

\section{A. Kesimpulan}

Dari hasil penelitian ex post facto mengenai pengaruh block grant kecakapan hidup terhadap hasil belajar bahasa Inggris pada tahun 2003 ada beberapa kesimpulan yang diperoleh seperti berikut.

a. Hasil pengujian dengan ANOVA dapat disimpulkan bahwa secara keseluruhan hasil belajar bahasa Inggris pada siswa yang memperoleh block grant lebih baik dibandingkan dengan siswa yang tidak memperoleh block grant.

b. Terdapat interaksi antara pemberian dana bantuan block grant kecakapan hidup dan kemampuan awal terhadap hasil belajar bahasa Inggris siswa. 


\section{B. Implikasi Penelitian}

Untuk bersaing di era global kemampuan bahasa Inggris sangat diperlukan baik bagi siswa-siswa yang melanjutkan ke perguruan tinggi maupun yang melanjutkan ke dunia kerja. Atas dasar itu Departemen Pendidikan Nasional melalui Direktorat Pendidikan Menengah Umum telah memberikan bantuan block grant kepada SMA Negeri dan Swasta sejak tahun 2002. Block grant ini di antaranya untuk melakukan reorientasi pembelajaran pada SMA yang bersangkutan dengan tujuan untuk meningkatkan proses pembelajaran yang pada akhirnya meningkatkan hasil belajar siswa. Dalam era globalisasi bahasa Inggris yang merupakan bahasa Internasional menjadi penting karena kemampuan berinteraksi sosial dengan semua pihak (Communication Skil) dengan menggunakan bahasa Inggris menjadi tuntutan profesionalisme baik dalam dunia kerja maupun dunia akademis. Untuk dapat bersaing dengan tenaga kerja dari negara-negara lain, kemampuan berbahasa Inggris tenaga kerja Indonesia harus ditingkatkan. Oleh karena itu implikasi hasil penelitian ini adalah sebagai berikut.

Pertama, berdasarkan hasil penelitian bahwa hasil belajar siswa SMA yang memperoleh block grant lebih baik daripada siswa yang tidak memperoleh block grant. Ini berarti pemberian block grant khususnya kegiatan reorientasi pembelajaran bahasa Inggris dapat membantu sekolah melengkapi sarana atau media pembelajaran berupa kaset audio dan vidio pembelajaran bahasa Inggris. Hal ini memungkinkan guru bahasa Inggris dapat meningkatkan proses pembelajaran menjadi lebih menarik dengan memanfaatkan berbagai macam media dan metode pembelajaran yang pada akhirnya meningkatkan hasil belajar bahasa Inggris siswa.

Kedua; Dari hasil penelitian ini juga diperoleh informasi bahwa siswa yang berkemampuan awal rendah yang memperoleh block grant, hasil belajar bahasa Inggrisnya lebih tinggi dibandingkan dengan siswa yang tidak memperoleh block grant. Hal ini terjadi 
karena guru-guru bahasa Inggris pada sekolah yang mendapat block grant dapat mendorong dan meningkatkan motivasi belajar bahasa Inggris siswa dengan menggunakan dan memanfaatkan berbagai jenis metode dan media pembelajaran yang menarik seperti kaset audio dan vidio pembelajaran bahasa Inggris. Pendekatan proses pembelajaran yang menggunakan dan memanfaatkan berbagai jenis metode dan media pembelajaran dapat meningkatkan hasil belajar bahasa Inggris siswa SMA, terutama sekali bagi siswa-siswa yang mempunyai nilai UAN bahasa Inggris SMP yang rendah.

Ketiga;, pemberian block grant akan sangat bermanfaat bagi sekolah-sekolah yang belum lengkap sarana pembelajarannya. Terutma sekolah-sekolah yang pada umumnya mempunyai siswa berkemampuan awal rendah dengan kondisi sekolah yang tidak mempunyai fasilitas dan media pembelajaran yang tidak memadai.

\section{Saran}

Bertolak dari hasil kesimpulan dan implikasi di atas, maka dapat disarankan beberapa hal sebagai berikut.

1. Block Grant Kecakapan Hidup sangat diperlukan khususnya bagi sekolah-sekolah di derah pinggiran kota, agar dapat meningkatkan hasil belajar siswa di sekolah tersebut. Jika program Block Granttidak dilanjutkan maka pemerintah dapat memberikan program bantuan lain yang dikhususkan untuk peningkatan mutu pembelajaran.

2. Pemanfaatan media pembelajaran dan penggunaan metode pembelajaran yang inovatif dan menarik harus diupayakan untuk dilakukan dalam proses pembelajaran baik pembelajaran bahasa Inggris maupun mata pelajaran-mata pelajaran lain.

3. Harus dilakukan penelitian lebih lanjut mengenai pengaruh Block Grant ataupun program bantuan yang lain terhadap 
mata pelajaran-mata pelajaran lain khususnya dalam meningkatkan hasil belajar siswa terutama mata pelajaranmata pelajaran yang penting seperti Bahasa Indonesia, Matematika, dan Sains. Selain itu juga perlu diadakan penelitian tentang dampak pemberian Block Grant Kecakapan Hidup yang bersifat vokasional terhadap lulusanlulusan SMA yang mendapat block grant yang telah bekerja di masyarakat dan instansi Pemerintah dan Swasta.

\section{KEPUSTAKAAN}

Alhumani, Amich. "Pendidikan Tinggi dan Pembangunan Ekonomi". Kompas. Jakarta: Jumat 6 Agustus 2004.

Ary, Donald, Jacobs, Lucy Cheser, dan Razaviech, Asghar. Introduction to Research in Education. New York: Holt, Rinehart and Winston. 1985.

Brolin, D.E. Life Centered Carer Education: A Competency Based

Approach. Reston VA: The Council for Exceptional Children.1989. CEFS Economic Opportunity Corporation. Community Services Block Grant (CSBG). http://www.advant.com/cefs/csbg.htm. 2005.

Departemen Pendidikan dan Budaya. Kurikulum Sekolah Menengah

Umum : Pelajaran Bahasa Inggris. Jakarta: Depdikbud. 1993. . Konsep Dasar Pendidikan Kecakapan Hidup. Jakarta:

Depdiknas. 2004.

. Kurikulum Berbasis Kompetensi. http://www.puskur.or.id. . Pedoman Pelaksanaan Pemberian Block Grant

Pendidikan Menengah Umum 2004. Jakarta: Dikmenum. 2004. . Rencana Pembangunan Tahunan (REPETA) Departemen

Pendidikan Nasional Tahun 2004. Jakarta: Depdiknas. 2003.

Rencana Strategi Pembangunan Pendidikan, Pemuda

dan Olahraga. Jakarta: Depdiknas. 2001.

2003

Statistik Pendidikan Tinggi 2002/2003. Jakarta: Balitbang. Statistik Persekolahan SMU 2002/2003. Jakarta: Balitbang.

2003. 
2003 Tentang Sistem Pendidikan Nasional. Jakarta: Depdiknas. 2003.

Degeng, I. Nyoman S. IImu Pengajaran: Taksonomi Variabel. Jakarta:

Ditjen Dikti Depdikbud. 1989.

Fatah, Nanang. Ekonomi dan Pembiayaan Pendidikan. Bandung:

PT. Remaja Rosdakarya. 2002.

Furcham, Arief. Pengantar Penelitian Dalam Pendidikan. Surabaya:

Usaha Nasional. 1982.

Gagne, Robert M. Kondisi Belajar dan Teori Pembelajaran, diterjemahkan oleh Munandir. Jakarta: PAU Proyek Pengembangan

Pusat Fasilitas Bersama Antar Universitas/UIC. 1989.

Wiston. 1977.

Gagne, Robert M. and Briggs, Leslie J. Principles of Instructional Design,

second edition. New York: Holt, Pinehart and Winstone. 1979.

Kariman, Tina Mariana. Strategi Pembelajaran Abad 21, dalam Makalah

Seminar Teknologi Pembelajaran. Jakarta: IPTPI. 2002.

Poerwadarminta, WJS. Kamus Umum Bahasa Indonesia. Jakarta: Balai

Pustaka. 2002.

Ragan, Tillman J., dan Smith, Patricia L. Conditions-Based Model for

Designing Instruction. (ed.). Handbook of Research for Educational

Communications and Technology. New York: Macmillan Library

Reference USA. 1996.

Reigeluth, Charles M. Instructional-Design Theories and Models.

London: Lawrence Erlbaum Associates, Publishers. 1983.

Singarimbun, Masri dan Effendi, Sofyan. Metode Penelitian Survey. Jakarta: LP3ES. 1989.

Sudjana. Metoda Statistika. Bandung: Tarsito. 1992.

Tim BBE Depdiknas. Pola Pelaksanaan Pendidikan Kecakapan Hidup.

Surabaya: SIC bekerjasama dengan LPM UNESA. 2003. 